DOI: $10.21802 / \operatorname{artm} .2020 .3 .15 .118$.

УДК 616-089.48: 616.36-008.5

\title{
ЗАСТОСУВАННЯ ЧЕРЕЗШКІРНИХ ЧЕРЕЗПЕЧІНКОВИХ ВТРУЧАНЬ ПРИ МЕХАНІЧНІЙ ЖОВТЯНИЦІ ПУХЛИННОї ЕТІОЛОГІї
}

\author{
О.В. Лукавецький, Т.М. Іванків, Я.Р. Дутка, Б.І. Бакум, М.П. Попик
}

\author{
Львівський національний медичний університет імені Данила Галищького, кафедра хірургї̈ №1, \\ м. Львів, Украӥна, \\ ORCID ID: 0000-0002-3998-6749, ORCID ID: 0000-0003-4095-9614, \\ ORCID ID: 0000-0002-2858-7216, ORCID ID: 0000-0002-7008-4815, \\ ORCID ID: 0000-0001-6841-1242, \\ e-mail:ivankiv_taras@bigmir.net
}

Резюме. Цілі. Лікування хворих із обтураційною жовтяницею пухлинної етіології пов’язане з великим ризиком для життя пацієнта, супроводжується високою летальністю, яка сягає при пухлинній обструкції біліарної системи 30,3 - 33\%. Черезшкірні втручання дозволяють приготувати пацієнта до радикального втручання та допомогти інкурабельним пацієнтам.

Методи. Проаналізовано результати черезшкірного черезпечінкового дренування біліарної системи у 47 пацієнтів з механічною жовтяницею пухлинної етіології. Черезшкірне черезпечінкове дренування жовчних проток (ЧЧДЖП) - у 28 (59,6\%) хворих; черезшкірне черезпечінкове дренування жовчного міхура (ЧЧДЖМ) у $19(40,4 \%)$ хворих. Показання: механічна жовтяниця, що супроводжує пацієнтів 3 пухлиною головки підшлункової залози, дистального відділу холедоха, холангіокарциномою воріт печінки, метастазами або збільшеними лімфатичними вузлами у воротах печінки.

Результати дослідження. Застосовували два способи дренування жовчних проток - за Сельдінгером переважно у хворих з ЧЧДЖП та одномоментне дренування переважно у хворих з ЧЧДЖМ. ЧЧДЖМ використали як перший етап для дренування жовчних проток перед радикальною операцією, ЧЧДЖП - у пацієнтів із занедбаними формами злоякісних пухлин для лікування механічної жовтяниці. У всіх хворих відновлено пасаж жовчі, ліквідовано явища холангіту і свербіж шкіри. Ускладнення трапилися у 7 (14,9\%) пацієнтів.

Висновки Черезшкірні черезпечінкові втручання ефективні при пухлинній обструкції, ліквідовують механічну жовтяницю і нормалізують гомеостаз, черезшкірне черезпечінкове дренування жовчного міхура дозволяє підготувати пацієнтів до радикальних хірургічних втручань.

Ключові слова: механічна жовтяниця, холангіт, черезшкірне черезпечінкове дренування.

Вступ. Лікування хворих із обтураційною жовтяницею пухлинної етіології $\epsilon$ складною, не вирішеною на теперішній час проблемою $[1,3,10]$. В умовах обтурації жовчних проток, холангіту і печінкової недостатності хірургічне лікування пов'язане 3 великим ризиком для життя пацієнта та супроводжується високою летальністю, яка складає при пухлинній обструкції біліарної системи 30,3 - 33\% [5, 9]. Високу летальність після операцій, проведених на тлі тривалої жовчної гіпертензії, пояснюють невідповідністю між компенсаторними можливостями печінки і важкістю операційного втручання [2, 5, 8]. У зв'язку з цим на першому етапі лікування пропонують здійснити декомпресію біліарного тракту для відновлення функції печінки та нормалізації гомеостазу. Черезшкірні втручання дозволяють приготувати пацієнта до радикального втручання, допомогти неоперабельним пацієнтам, також ці методи часто не мають альтернативи для порятунку безнадійних хворих $[2,4,6,7]$.

Обгрунтування дослідження. Механічна жовтяниця є пізнім виявом пухлин панкреатобіліарної зони. На час поступлення в хірургічний стаціонар лише близько чверті всіх пацієнтів підлягають радикальному операційному втручанню. Як перший етап лікування застосовують дренування жовчних проток. Вибір методу підготування хворих із обтураційною жовтяницею пухлинної етіології до радикальної операції залишається невирішеним питанням біліарної хірургії. Перевага надається малоінвазійним втручанням, проте застосування конкретного методу дренування жовчних проток залишається дискутабельним.

Мета дослідження. Вивчити можливість i безпечність підготування пацієнтів 3 механічною жовтяницею та холангітом на грунті пухлинної обструкції біліарної системи до радикального операційного втручання та з'ясувати ефективність черезшкірного черезпечінкового дренування жовчних проток у неоперабельних хворих.

Матеріали та методи досліджень. Нами проаналізовано результати черезшкірного черезпечінкового дренування 47 пацієнтів 3 механічною жовтяницею пухлинної етіології, які знаходилися на стаціонарному лікуванні в клініці в період від квітня 2018 до січня 2020 року. Жінок було 20 (42,5\%), чоловіків - 27 (57,5\%); середній вік хворих - 58,6 $\pm 11,2$ років. Всім пацієнтам із обтураційною жовтяницею було виконано малоінвазійні втручання під ультразвуковим контролем: черезшкірне черезпечінкове 
дренування жовчних проток (ЧЧДЖП) - у 28 (59,6\%) хворих; черезшкірне черезпечінкове дренування жовчного міхура (ЧЧДЖМ) - у 19 (40,4\%) хворих. При виконанні ЧЧДЖМ використовували дренаж типу Dawson-Mueller 8,5Fr, а при ЧЧДЖП - дренажний набip Rusch Teleflex 8F. Показанням до виконання черезшкірного черезпечінкового жовчовивідного дренування під контролем ультрасонографії у цих хворих були: механічна жовтяниця (рис.1), синдром холестазу, нестерпний свербіж шкіри і холангіт, що супроводжує пацієнтів 3 пухлиною головки підшлункової залози, пухлиною дистального відділу холедоха, холангіокарциномою воріт печінки, метастазами або збільшеними лімфатичними вузлами у воротах печінки при раку шлунка, шийки матки та грудної залози.

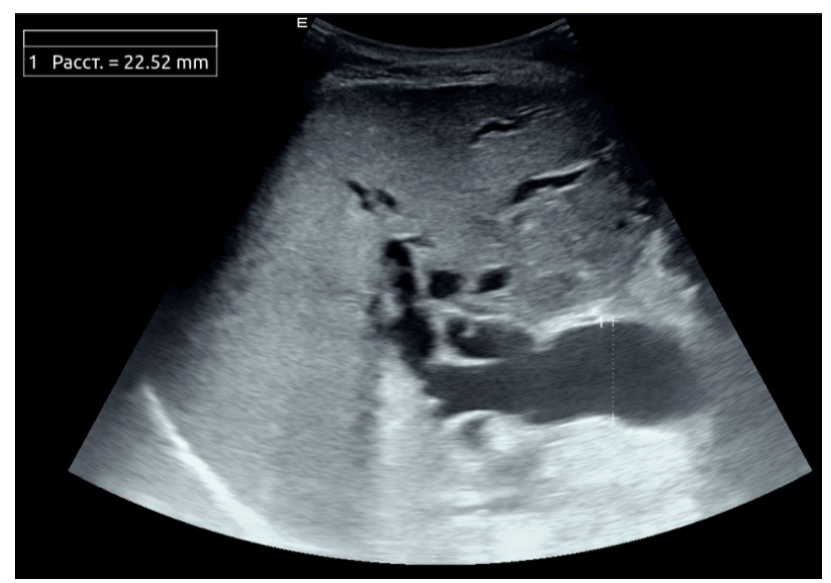

Рис. 1. УСГ паціснта з механічною жовтяницею при плануванні ЧЧДжП

Результати дослідження. Черезшкірні черезпечінкові втручання проводили для приготування до радикального оперативного втручання; як основний метод лікування пацієнтів із занедбаними формами злоякісних пухлин та складній анатомії шлунка, дванадцятипалої кишки, великого дуоденального соска для проведення ендоскопічних транспапілярних втручань (деформація папіли та іiі розміщення у складці кишки, довгий інтрамуральний хід папіли, парапапілярні дивертикули, деформація зі звуженням дистального відділу холедоха, деформація i дилятація шлунка та дванадцятипалої кишки, пов'язана зі зростами або супровідною патологією, стеноз воротаря, виражений набряк складок дванадцятипалої кишки, виразка дванадцятипалої кишки в періампулярній зоні, попередні операції на шлунку - резекція Більрот-II, гастректомія i дванадцятипалій кишці).

Результати хірургічного лікування хворих із обтураційною жовтяницею пухлинної етіології залежать від термінів виконання операційного втручання, важкості печінкової недостатності, а також від способу та об'єму операції. Для цього перед традиційним втручанням проводили черезшкірні черезпечінкові втручання, які не позбавляли пацієнтів від причини хвороби, але дозволяли добитися ліквідації або зниження жовтяниці, свербіжу шкіри, холангіту і запобігти печінковій недостатності. 3 цією метою ЧЧДЖМ (рис.2) як перший етап лікування проведено у 19 хворих: 17 (89,5\%) 3 пухлиною головки підшлункової залози та $2(10,5 \%)-3$ пухлиною дистального відділу холедоха. Наступним етапом після відновлення функції печінки та нормалізації гомеостазу всім хворим через $2-4$ тижні проведено радикальні операційні втручання.

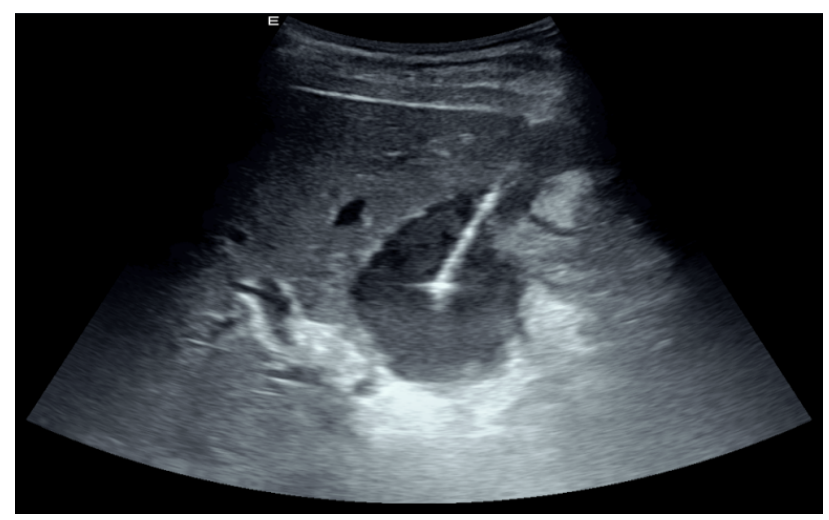

Рис. 2. Встановлення дренажа у жовчний міхур під УСГ-контролем

Черезшкірне черезпечінкове дренування жовчних проток (рис.3) застосували у пацієнтів із занедбаними формами злоякісних пухлин, серед яких: 16 хворих 3 пухлиною головки підшлункової залози (з них 5 (31,3\%) після операційного лікування), 3 - $з$ пухлиною дистального відділу холедоха, 2 3 холангіокарциномою воріт печінки, 5 - 3 рецидивом раку шлунка та по одному - 3 метастазами раку шийки матки і грудної залози. При дренуванні біліарного дерева 28 хворих дренаж проведено у протоку правої частки печінки у 22 (78,6\%) пацієнтів, у протоку лівої частки - у $5(17,9 \%)$ та в одного $(3,6 \%)$ - білатеральHo.

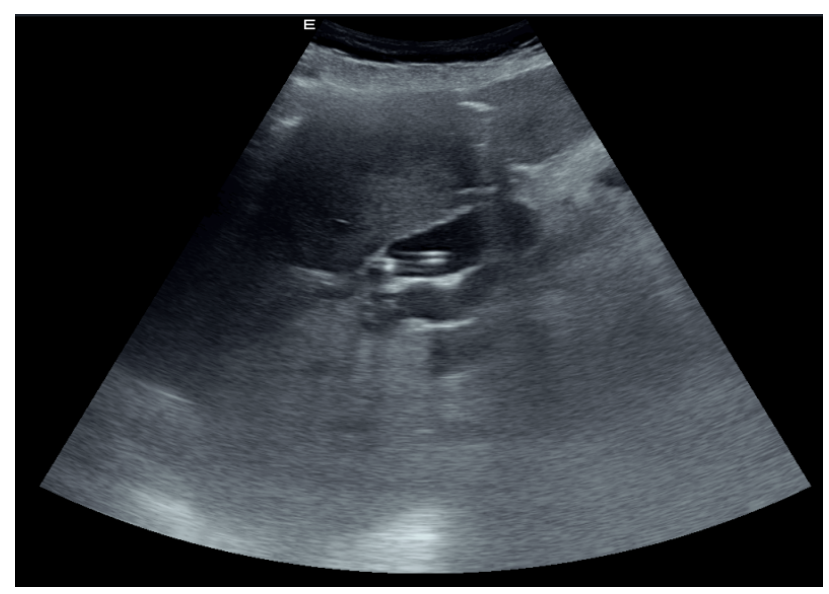

Рис. 3. Дренаж у загальній жовчній протоці

Абсолютними протипоказаннями до проведення черезшкірних черезпечінкових жовчовивідних втручань були термінальний стан хворого та наявність асциту. Відносні протипоказання - це відсутність безпечної траєкторії для проведення голки та 
дренажу, обширне пухлинне ураження печінки із відокремленням внутрішньопечінкових жовчних проток на рівні сегментарних (IV тип за Bismuth), виражені порушення системи згортання крові.

Місце для пункції при ЧЧДЖМ обирали у правому підребер'ї індивідуально із врахуванням розташування жовчного міхура. ЧЧДЖП виконували у точках по передній аксілярній лінії у VIII міжребер’ї для дренування правої печінкової протоки та в епігастрію по серединній лінії для дренування лівої печінкової протоки.

Застосовували два способи дренування жовчних проток під контролем ультрасонографії:

- двомоментний спосіб дренування за Сельдінгером у $27(96,4 \%)$ хворих з ЧЧДЖП та у $3(15,8 \%) 3$ ЧЧДЖМ;

- одномоментне дренування стилет-катетером у 16 $(84,2 \%)$ хворих 3 ЧЧДЖМ та одного $(3,6 \%) 3$ чЧДЖП.

При холангіті у 5 (10,6\%) пацієнтів проводили санацію біліарного дерева розчином антисептика.

Усім пацієнтам проводили контроль УСГ через 2 - 3 години та у першу добу після втручання та визначали такі показники:

- діаметр жовчних проток та розміри жовчного міхура;

- кровоплин по печінковій артерії та портальній вені;

- наявність рідинних скупчень у черевній порожнині.

У всіх хворих відновлено пасаж жовчі, зменшено явища механічної жовтяниці та ліквідовано явища холангіту і свербіж шкіри.

Ускладнення трапилися у 7 (14,9\%) пацієнтів. Ранніми ускладненнями були: підтікання жовчі попри дренажну трубку у одного з них та внутрішньопечінкові гематоми у 2 пацієнтів. Пізнім ускладненням була міграція дренажу 3 просвіту жовчних проток назовні у 4 хворих, яким дренаж встановлено повторно.

Обговорення результатів. Черезшкірне черезпечінкове дренування біліарної системи пацієнтів 3 механічною жовтяницею пухлинної етіології за нашими результатами є дієвим, відносно безпечним методом лікування. У всіх хворих відновлено пасаж жовчі, зменшено явища механічної жовтяниці та ліквідовано прояви холангіту і свербіж шкіри. Черезшкірне черезпечінкове дренування жовчних проток застосовуємо у пацієнтів із занедбаними формами злоякісних пухлин для паліативного відведення жовчі та покращення загального стану хворих. Черезшкірне черезпечінкове дренування жовчного міхура застосовуємо як перший етап лікування пацієнтів для підготування до операції. Наступним етапом після відновлення функції печінки та нормалізації гомеостазу всім хворим через $2-4$ тижні проведено радикальні операційні втручання.

Проте необхідне подальше опрацювання результатів черезшкірних черезпечінкових втручань під контролем ультрасонографії для всебічного та достеменного вивчення всіх можливостей методу і запобігання розвитку небезпечних для життя ускладнень.

\section{Висновки:}

1. Малоінвазійні черезшкірні черезпечінкові втручання $є$ ефективним способом відведення жовчі при пухлинній обструкції біліарної системи, які дозволяють ліквідувати механічну жовтяницю.

2. Черезшкірне черезпечінкове дренування жовчного міхура під контролем ультрасонографії дозволяє підготувати пацієнтів до радикальних планових хірургічних втручань.

3. Необхідне подальше опрацювання оптимальної хірургічної тактики у хворих 3 механічною жовтяницею пухлинного генезу.

\section{References:}

1. Tkachuk OL, Shabat GI. Vubir metody biliarnoiy dekomresiy pry mechanychnyi zhovtyanucy puhlunnoyi ethiologyi. Galytskyi likarskyi visnuk. 2012; 19(4):160-162.

2. Aiura K, Shinoda M, Nishiyama R. Surgical technique for complete resection of the extrahepatic portion of the common bile duct and the ampulla of Vater for tumors of the ampulla of Vater. J. Hepatobiliary Pancreat Sci. 2010; Jul, 8.

3. Aljiffry M, Abdulelah A., Walsh M., Peltekian K, et al. Evidence-based approach to cholangiocarcinoma: a systematic review of the current literature. J. Am. Coll. Surg. 2009; 208(1):134-147.

4. Van Delden OM, Lameris JS. Percutaneous drainage and stenting for palliation of malignant bile duct obstruction // Eur Radiol. 2008; 18:448-456.

5. Garcarek J, Kurcz J, Guziński M, Janczak D, Sasiadek $M$. Ten years single center experience in percutaneous transhepatic decompression of biliary tree in patients with malignant obstructive jaundice. Adv Clin Exp Med. 2012; 21:621-632.

6. Gamanagatti S, Singh T, Sharma R, Srivastava DN, Dash NR, Garg PK. Unilobar versus bilobar biliary drainage: Effect on quality of life and bilirubin level reduction. Indian J Palliat Care. 2016; 22:50-62.

7. Lee JW, Han JK, Kim TK, Choi BI, Park SH, Ko YH, Yoon CJ, Yeon KM: Obstructive jaundice in hepatocellular carcinoma: response after percutaneous transhepatic biliary drainage and prognostic factors. Cardiovasc Intervent Radiol. 2002; 25(3):176-179.

8. Liu YS, Lin CY, Chuang MT, Tsai YS, Wang CK, Ou MC. Success and complications of percutaneous transhepatic biliary drainage are influenced by liver entry segment and level of catheter placement. Abdom Radiol (NY). 2018; 43(3):713-722.

9. Qian XJ, Zhai RY, Dai DK, Yu P, Gao L. Treatment of malignant biliary obstruction by combined percutaneous transhepatic biliary drainage with local tumor treatment. World J Gastroenterology. 2006; 12:331335.

10. Shao JH, Fang HX, Li GW, He JS, Wang BQ, Sun JH. Percutaneous transhepatic biliary drainage and stenting for malignant obstructive jaundice: A report of two cases // Exp Ther Med. - 2015. - Vol.94. P.1503-1506. 


\section{УДК 616-089.48: 616.36-008.5 \\ ПРИМЕНЕНИЕ ЧЕРЕЗКОЖНЫХ \\ ЧЕРЕЗПЕЧЕНОЧНЫХ ВМЕШАТЕЛЬСТВ ПРИ МЕХАНИЧЕСКОЙ ЖЕЛТУХЕ ОПУХОЛЕВОЙ ЭТИОЛОГИИ}

\author{
А.В. Лукавецкий, Т.М. Иванкив, Я.Р. Дутка, \\ Б.И. Бакум, М.П. Попык
}

Львовский национальньий медицинский университет имени Данила Галииєкого, кафедра хирургии №1,

2. Львов, Украина,

ORCID ID: 0000-0002-3998-6749,

ORCID ID: 0000-0003-4095-9614

ORCID ID: 0000-0002-2858-7216,

ORCID ID: 0000-0002-7008-4815,

ORCID ID: 0000-0001-6841-1242,

e-mail:ivankiv_taras@bigmir.net

Резюме. Цель. Лечение больных с механической желтухой опухолевой этиологии связано с большим риском для жизни пациента и сопровождается высокой летальностью, составляющей 30,3 $33 \%$. Черезкожные вмешательства разрешают подготовить пациента до операционного вмешательства и помочь инкурабельным пациентам.

Методы. Проанализированы результаты черезкожного черезпеченочного дренирования билиарной системы у 47 пациентов с механической желтухой опухолевой этиологии. Черезкожное черезпеченочное дренирование желчных (ЧЧДЖ) проток - у 28 (59,6\%) больных; черезкожное черезпеченочное дренирование желчного (ЧЧДЖ) пузыря - у 19 (40,4\%) больных. Показания: механическая желтуха, синдром холестаза, кожный зуд, холангит, сопровождающий пациентов с опухолью головки поджелудочной железы, дистального отдела холедоха, холангиокарциномой ворот печени, метастазами или увеличенными лимфатическими узлами в воротах печени.

Результаты исследования. Использовали два способа дренирования желчных проток - за Сельдингером главным образом у больных с ЧЧДЖ проток и одномоментное дренирование главным образом у больных с ЧЧДЖ пузыря. ЧЧДЖ пузыря использовали как первый этап для дренирования билиарной системы перед радикальным операционным вмешательством, ЧЧДЖ проток - у пациентов с запущенной формой злокачественных новообразований для лечения механической желтухи. У всех больных восстановлено пассаж желчи, ликвидировано явления холангита и кожный зуд. Осложнения были у 7 (14,9\%) пациентов.

Выводы. Черезкожные черезпеченочные вмешательства эффективны при опухолевой обструкции, ликвидируют механическую желтуху и нормализируют гомеостаз, разрешают подготовить пациентов к радикальным операционным вмешательствам.

Ключевые слова: механическая желтуха, холангит, черезкожное черезпеченочное дренирование.
UDC 616-089.48: 616.36-008.5

THE USE OF INTERCUTAL TRANSHEPATIC

INTERVENTIONS IN MECHANICAL JAUNDICE OF TUMOR ORIGIN

O.V. Lukavetsky, T.M. Ivankiv, Ya.R. Dutka,

B.I. Bakum, M.P. Popyk

Danylo Galytskyj National Medical University of Lviv, department of surgery №1,

Lviv, Ukraine,

ORCID ID: 0000-0002-3998-6749,

ORCID ID: 0000-0003-4095-9614,

ORCID ID: 0000-0002-2858-7216,

ORCID ID: 0000-0002-7008-4815,

ORCID ID: 0000-0001-6841-1242,

e-mail: ivankiv_taras@bigmir.net

Abstract. Introduction. The treatment of patients with obstructive jaundice of tumor etiology is connected with a high risk to patients lives and is followed by a high mortality level, which in the case of tumor obstruction of biliary system is $30,3-33 \%$. That is why the decompression of the biliary tract is suggested at the first stage of treatment. Intercutal interventions will help to prepare the patients for the radical interventions and help inoperable patients and these methods do not give the alternative for the sarvation of hopeless patients.

Methods. The results of intercutal thanshepatic dreinage of 47 patients with mechanical jaundice of tumor etiology under the control of ultrasonography have been analysed. Intercutal transhepatic drairage of bile ducts (ITDBD) was conducted in $28(59,6 \%)$ patients and itercutal transhepatic drainage of gallbladder (ITDG) in $19(40,4 \%)$ patients. The indications for this drainage under the control of ultrasonography were mechanical jaundice, choleostasis syndrom, unbearable skin itching and cholangitis in case of patients with the head pancreas tumor, cholangiocarcinoma of the liver gate, metastases or enlarged lymph nodes in the liver gates in case of stomach cancer, cervix or breast cancer.

The results of research. Intercutal transhepatic intervention were conducted to restore radical operative intrusion; as the main method of treatment of patients with neglected forms of tumours and complicated anatomy of ventricle, duodenum, papilla and also for conduction of endoscopic transpapillar intervention.

Two methods of bile ducts drainage were usedthe two- step method of dreinage by Seldinger, mainly in case of patients with (ITDBD) and the one- step method of drainage with a stylet catheter, mainly of patients with (ITDG). ITDBD in $28(59,6 \%)$ patients was used as the first stage for the drainage of the bile ducts before the radical operation for the function recovery of liver and homeostasis normalization, ITDG - in 19 (40,4\%) patients with the neglected form of malignant tumor for the treatment of mechanical jaundice. Two methods of bile ducts drainage were used under the control of ultrasonography: the two-step method by Seldinger in case of 27 $(96,4 \%)$ patients with ITDBD and $3(15,8 \%)$ with ITDG and the one-step method of drainage with the help of 
stylet catheter $16(84,2 \%)$ with ITDBG and one $(3,7 \%)$ with ITDG.

Absolute contraindications to intercutal transhepatic bile ducts interventions were terminal state of the patient and the availability of ascites. Relevant contraindications are the absence of safe trajectory for the needle conduction or drainage, massive tumor lesion of liver with transhepatic bile ducts separation on segment level (IV type by Bismuth), severe violations in blood coagulation system.

The bile passage was restored, the manifistations of mechanical jaundice were reduced and the signs of cholangitis and skin itcing were eliminated in all patients. There were complications in $7(14,9 \%)$ patients.
Conclusions. Minimally invasive intercutal transhepatic interventions are an effective way of withdrawl of bile in case of tumor obstruction of biliary system which helps to liquidate mechanical jaundice and normalize homeostasis, intercutal transhepatic drainage of gallbladder under the control of ultrasonography gives an opportunity to prepare patients for radical surgical interventions. It is necessary to work on further optimal surgical tactics in case of patients with mechanical jaundice of tumor genesis.

Keywords: mechanical jaundice, cholangitis, intercutal transhepatic drainage.

Стаття надійшла в редакцію 19.06.2020 р. 